\title{
Erratum: Agter elke man: Onderweg na inklusiewe taalgebruik in die Afrikaanse kerklied
}

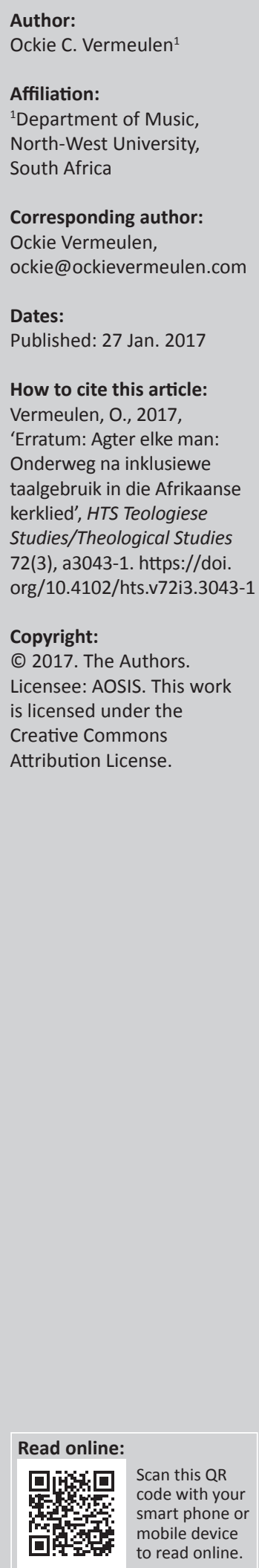

Published: 27 Jan. 2017

How to cite this article:

Vermeulen, O., 2017,

'Erratum: Agter elke man:

Onderweg na inklusiewe taalgebruik in die Afrikaanse kerklied', HTS Teologiese Studies/Theological Studies 72(3), a3043-1. https://doi. org/10.4102/hts.v72i3.3043-1

Copyright:

(C) 2017. The Authors.

Licensee: AOSIS. This work

is licensed under the

Creative Commons

Attribution License.

The Editor regrets that the article was inadvertently allocated to an incorrect issue of HTS Teologiese Studies/Theological Studies upon its online publication.

The article belongs in, HTS Teologiese Studies/Theological Studies, 2016, Volume 72, Issue 3.

The Editor apologises. 